ARTICLE

\title{
Massive carbon storage in convergent margins initiated by subduction of limestone
}

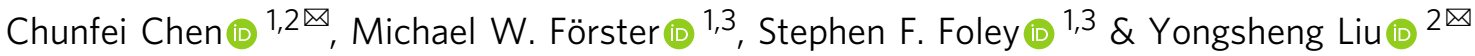

Remobilization of sedimentary carbonate in subduction zones modulates arc volcanism emissions and thus Earth's climate over geological timescales. Although limestones (or chalk) are thought to be the major carbon reservoir subducted to subarc depths, their fate is still unclear. Here we present high-pressure reaction experiments between impure limestone ( $7.4 \mathrm{wt} . \%$ clay) and dunite at 1.3-2.7 GPa to constrain the melting behaviour of subducted natural limestone in contact with peridotite. The results show that although clay impurities significantly depress the solidus of limestone, melting will not occur whilst limestones are still part of the subducting slab. Buoyancy calculations suggest that most of these limestones would form solid-state diapirs intruding into the mantle wedge, resulting in limited carbon flux to the deep mantle $\left(<\sim 10 \mathrm{Mt} \mathrm{C} \mathrm{y}^{-1}\right)$. Less than $20 \%$ melting within the mantle wedge indicates that most limestones remain stable and are stored in subarc lithosphere, resulting in massive carbon storage in convergent margins considering their high carbon flux $\left(\sim 21.4 \mathrm{Mt} \mathrm{C} \mathrm{y}^{-1}\right)$. Assimilation and outgassing of these carbonates during arc magma ascent may dominate the carbon flux in volcanic arcs.

\footnotetext{
${ }^{1}$ Department of Earth and Environmental Sciences and ARC Centre of Excellence for Core to Crust Fluid Systems, Macquarie University, North Ryde, NSW Australia. ${ }^{2}$ State Key Laboratory of Geological Processes and Mineral Resources, School of Earth Sciences, China University of Geosciences, Wuhan, China.

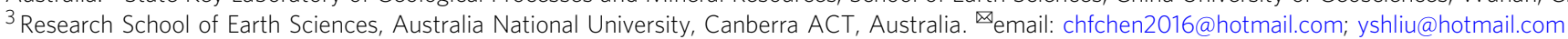


T ectonic activity has been invoked as the driver of icehousegreenhouse intervals because variations of volcanic emissions in convergent margins exert considerable control on atmospheric $\mathrm{CO}_{2}$ levels and thus climate on timescales of millions of years ${ }^{1,2}$. Subduction has the ability to transport large amounts of carbon (modern carbon flux: 68-96 Mt C $\mathrm{y}^{-1}$ ) to replenish the mantle carbon reservoir at convergent margins $s^{3,4}$. However, most of the subducted carbon has been suggested to be released beneath forearcs and arcs and relatively little carbon may be recycled to the convecting mantle ${ }^{5-7}$. Furthermore, substantial quantities of the released carbon were interpreted to be stored in the crust and mantle lithosphere as the amount of $\mathrm{CO}_{2}$ emitted from arc volcanoes appears to be less than that subducted ${ }^{5}$. Understanding the behaviour of carbon in subduction zones and its storage in convergent margins is critical to grasping how tectonic activity controls the Earth's climate.

Carbon is concentrated in sediments (carbonated siliciclastic and limestone; $\left.\sim 60 \mathrm{Mt} \mathrm{C}^{-1}\right)$, altered oceanic crust $\left(\sim 18 \mathrm{Mt} \mathrm{C} \mathrm{y}^{-1}\right)$, and suboceanic mantle layers (1.3-10 Mt C $\left.{ }^{-1}\right)$ in modern subducting slabs (Fig. 1a) ${ }^{8}$. Among diverse subducted materials, the marble derived from limestone and chalk carries about $25 \%$ of this subducted carbon ( 21.4 Mt C y $\left.{ }^{-1}\right)^{3,6}$. Recently, Stewart and Ague ${ }^{6}$ indicated that most of the carbon in the carbonated siliciclastic and altered oceanic crust $(>90 \%)$ is released via metamorphic decarbonation reactions during infiltration of a water-bearing fluid at forearc depths (Fig. 1a). Limestone that survives this metamorphic decarbonation is an important or major carrier for transporting carbon to subarc depths (Fig. 1a) ${ }^{6}$. The carbonate dissolution and hydrous melting of carbonate-bearing crustal materials were advocated as two potential pathways for transferring subducted carbon to the mantle wedge at subarc depths ${ }^{9-11}$. However, the efficiency of these two mechanisms depends on the production of fluid and the mode of fluid percolation (channelled vs. pervasive) in dynamic subduction processes ${ }^{12}$. Fully hydrated oceanic crust loses about two-thirds of its initial water content in the pressure interval below $2 \mathrm{GPa}$; the efficiency of carbonate dissolution has not been investigated at higher pressures 9,13 . The fate of marble is poorly constrained. Experimental studies have largely under-evaluated the role of pure and nearly pure limestone or chalk, emphasising instead a global weighted average composition of subducted sediments (Fig. 1b), corresponding to clastic sediments with 7 wt.\% carbonates ${ }^{14}$. This models the global sedimentary carbon contribution to subduction ${ }^{15-18}$, but ignores the behaviour of carbonate-rich rocks that make up a substantial proportion of the subducted carbonate ${ }^{3}$. A number of studies have speculated that diapirism of buoyant sedimentary materials could provide an additional pathway for recycled crustal carbonate to rise into the mantle wedge due to their low density and high melting temperature ${ }^{5,15-18}$ but as yet, no experimental studies have investigated the fate of limestone diapirs within the mantle wedge.

In this study, we have conducted reaction experiments at 1.3-2.7 GPa and $900-1200^{\circ} \mathrm{C}$ between a limestone from Ocean Discovery Program site ODP 115-714 A and a geochemically depleted peridotite (dunite) from Hannuoba, north China (see "Methods"), which were loaded as distinct, juxtaposed blocks into single experimental capsules. The limestone contains 7.4 wt.\% clay and has a chemical composition similar to average global limestone and chalk (Fig. 1b). Importantly, its $\mathrm{H}_{2} \mathrm{O}$ content is similar to those of subducted marbles (Fig. 1c). These reaction experiments can be used to constrain the melting behaviour of limestone in contact with peridotite at the slab-mantle interface and of limestone diapirs during their rise through the peridotite mantle wedge. Combined with buoyancy calculations, the present study suggests that most of these limestones will not melt in subduction zones or in the mantle wedge but will form limestone diapirs that are stored in arc lithosphere in the solid-state, resulting in massive carbon storage in convergent margins.

\section{Results}

Phase assemblages and solidus of limestone-peridotite interaction. The subsolidus mineral assemblages at all pressures consisted of olivine (47-48 wt.\%), calcite (46-48 wt.\%), and clinopyroxene (about 5 wt.\%) without hydrous minerals (Supplementary Table 1, phase modes are estimated by mass balance calculation (see "Methods")). The clinopyroxenes were distributed in the former limestone layer and in the reaction zone between calcite and olivine (Fig. 2a).

Close to the solidus, the carbonatite melt (dendritic quench structure) is restricted to the contact zone between limestone and olivine (Fig. 2 and Supplementary Fig. 1). The temperature at which carbonatite melt first appears increases from 950 to $1050^{\circ} \mathrm{C}$ as pressure increases from 1.3 to $2.7 \mathrm{GPa}$ (Fig. 3). The proportion of carbonatite melt is $5-10 \mathrm{wt} . \%$ in near-solidus experiments and increases with the temperature (Supplementary Table 1; Supplementary Fig. 2). The limestone layer is entirely molten at $1200^{\circ} \mathrm{C}$ and 2.0 GPa (Supplementary Fig. 1f). Interestingly, silicate melt is observed along boundaries between calcite crystals in the limestone layer away from the contact with dunite in the experiment at 2.7 GPa and $1100^{\circ} \mathrm{C}$ (Supplementary Fig. 3). These silicate melts
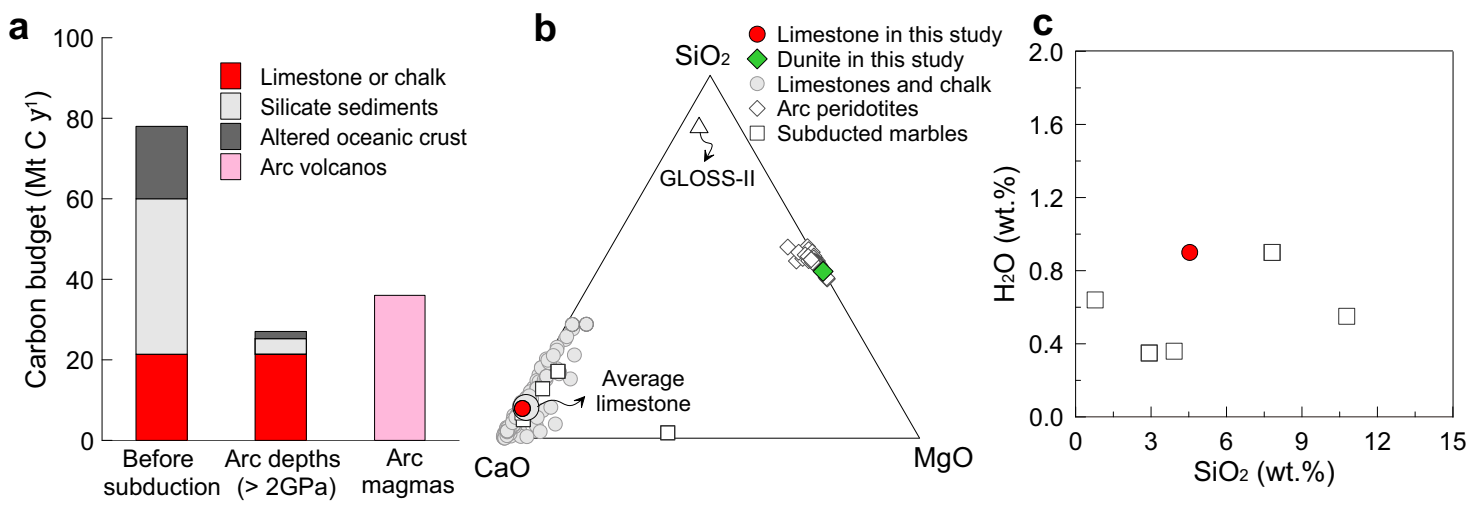

Fig. 1 Subduction carbon fluxes and chemical compositions of starting materials. a The constructed carbon budget in global subduction zones at forearc depths $s^{3,8}$ and subarc depths ${ }^{6}$. The carbon emission flux in arc volcanos is shown for comparison 4 . $\mathbf{b}$ The compositions of the limestone and dunite used as the starting materials in this study compared to natural marine limestones and arc peridotites (including harzburgites and dunites). The global weighted average composition of subducted sediments (GLOSS-II) is shown for comporison ${ }^{65}$. Data sources of natural marine limestones and arc peridotites are provided in the supplementary information. $\mathbf{c}$ The comparison of the water content of the limestone used as the starting material with marbles from the $\mathrm{S}$. W. Tianshan UHP subduction zone $(>2.1 \mathrm{GPa})^{32}$. 

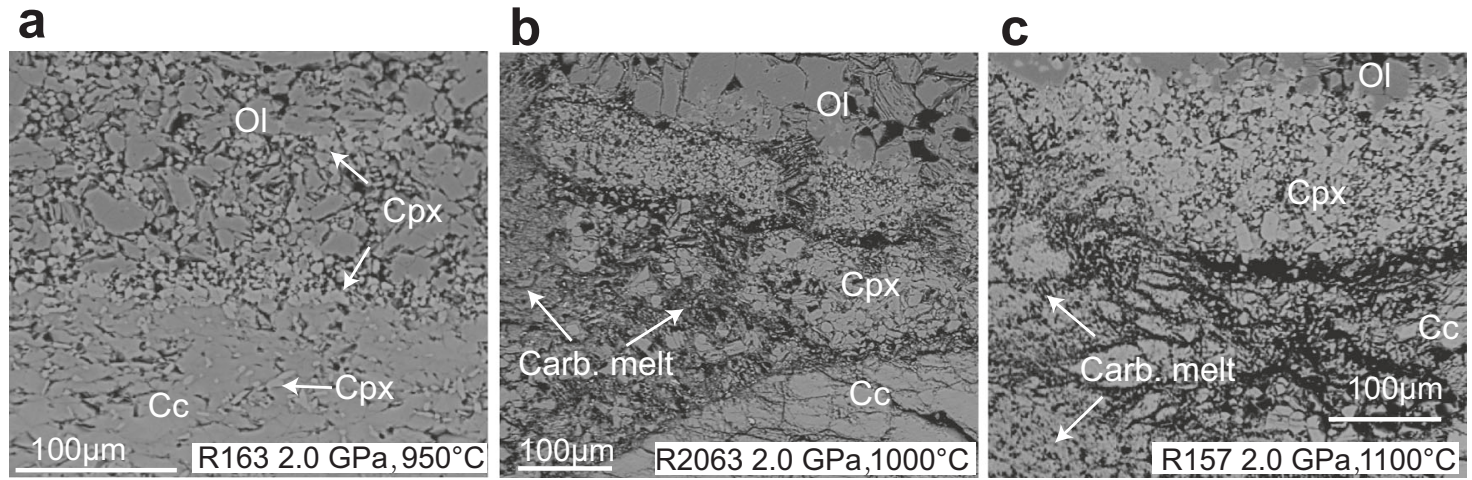

Fig. 2 Representative backscattered electron images of experimental charges. a Subsolidus and $\mathbf{b}, \mathbf{c}$ above-solidus temperatures at $2.0 \mathrm{GPa}$. Ol olivine, Cc calcite, Cpx clinopyroxene, Carb.melt carbonatite melt.

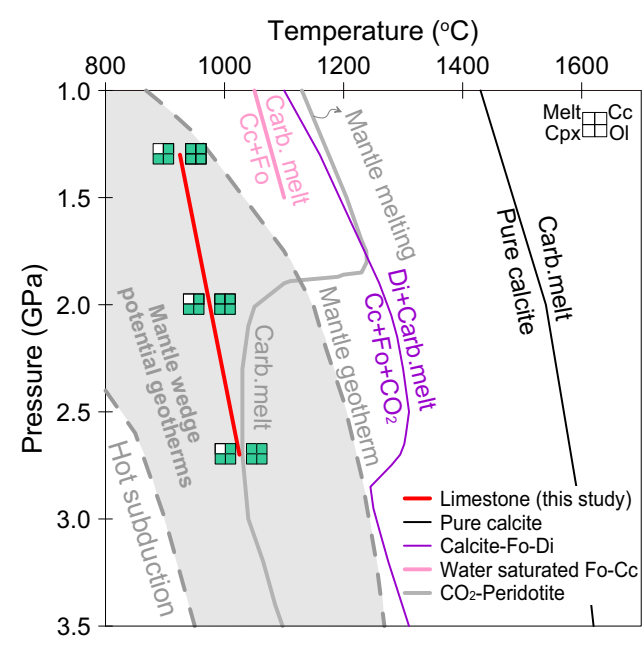

Fig. 3 The solidus curve of limestone in contact with dunite. The limestone solidus curve (red line: phases are shown in squares, Ol olivine, Cpx clinopyroxene, Cc calcite, and melt-carbonatite melt [top-left square]). Melting curves for pure calcite (black line ${ }^{20}$ ), the calcite-olivine-clinopyroxene system (purple line ${ }^{21,22}$ ), water-rich calcite-olivine system (pink line ${ }^{23}$ ), and peridotite $+\mathrm{CO}_{2}$ (grey line ${ }^{29}$ ), are shown for comparison. The solidus of limestone in contact with dunite is about $250^{\circ} \mathrm{C}$ lower than that of the

calcite-olivine-clinopyroxene system and lies between the subduction zone ${ }^{43}$ and mantle geotherms (represented by the SE Australia geotherm ${ }^{66}$ ). The grey region represents the potential geotherms of the mantle wedge, which is between hot subduction slab surface geotherms and normal continental lithosphere geotherms. Fo forsterite, Di diopside, Cc calcite.

are characterised by shoshonitic compositions with high $\mathrm{Na}_{2} \mathrm{O}$ and $\mathrm{K}_{2} \mathrm{O}$ contents (Supplementary Table 2; Supplementary Fig. 4). In contrast to the subsolidus mineral assemblages, the near-solidus experiments show a thick layer of clinopyroxene (about $150 \mu \mathrm{m})$ in a reaction zone between the former dunite and limestone layers (Fig. 2b). This layer formed as a reaction product as demonstrated by the occurrence of olivine inclusions in the newly grown clinopyroxenes (Supplementary Fig. 1e). The thickness of the clinopyroxene layer is almost constant with the increasing melting degrees at $<1200$ ${ }^{\circ} \mathrm{C}$ (Fig. 2b, c) and decreases when the limestone layer is entirely molten at $1200^{\circ} \mathrm{C}$ and $2 \mathrm{GPa}$. With increasing temperature, the olivine and calcite proportions decrease at all pressures.

Phase compositions. The clinopyroxenes in the reaction zones of the subsolidus experiments have 20.3-22.7 wt.\% $\mathrm{CaO}, 14.5-18.3$ wt.\%
$\mathrm{MgO}$, and $0.45-1.23$ wt.\% $\mathrm{Na}_{2} \mathrm{O}$ (Supplementary Data 1 ), whereas clinopyroxenes in reaction layers in the above-solidus experiments have much lower $\mathrm{Na}_{2} \mathrm{O}$ contents (0.04-0.38 wt.\%). Furthermore, the compositions of clinopyroxenes in the limestone layers are significantly different from those in the reaction zones, with a gradual change from high $\mathrm{Al}_{2} \mathrm{O}_{3}$ content and low $\mathrm{CaO} / \mathrm{Al}_{2} \mathrm{O}_{3}$ ratio in the former limestone to low $\mathrm{Al}_{2} \mathrm{O}_{3}$ content and high $\mathrm{CaO} / \mathrm{Al}_{2} \mathrm{O}_{3}$ ratio in the clinopyroxene layer (Supplementary Fig. 4). A similar gradual change in clinopyroxene compositions occurs during the reaction of clastic sediments and peridotite ${ }^{19}$. Olivines show a large variation in $\mathrm{CaO}$ contents (mostly 0.03-1.37 wt.\%), higher than those of starting materials (0.03 wt.\%). Their FeO contents decrease with increasing temperature due to Fe loss to the capsule (Supplementary Table 1). Calcites in the reaction zones of the subsolidus experiments show much higher $\mathrm{MgO}$ contents than those within the limestone layers (e.g. 10.4-10.5 wt.\% vs. $0.08-1.0$ wt. $\%$ at $2.7 \mathrm{GPa}$ and $1000^{\circ} \mathrm{C}$ ). Importantly, $\mathrm{MgO}$ contents of the calcites in reaction zones show a marked increase with increasing pressure $(2.8-3.5$ wt.\% at $1.3 \mathrm{GPa}$, 8.5-9.9 wt.\% at $2.0 \mathrm{GPa}$, and $10.4-10.5$ wt.\% at $2.7 \mathrm{GPa}$ ) (Fig. 4). Calcites in the limestone layers of the above-solidus experiments also have higher $\mathrm{MgO}$ contents than the starting materials, but lower than in calcites within the reaction zones of subsolidus experiments.

The silicate melts in the experiment at $2.7 \mathrm{GPa}$ and $1100{ }^{\circ} \mathrm{C}$ have high $\mathrm{SiO}_{2}$ (52.0-56.6 wt.\%), $\mathrm{Na}_{2} \mathrm{O}$ (1.27-1.52 wt.\%) and $\mathrm{K}_{2} \mathrm{O}$ (5.04-6.40 wt.\%), and low $\mathrm{MgO}$ (0.5-1.5 wt.\%) (Supplementary Data 1). Their major element totals are 88.2-91.2 wt.\%, indicating about 10-12 wt.\% volatiles (mostly $\mathrm{H}_{2} \mathrm{O}$ ) in the melts. The carbonatite melts rapidly quenched to glasses with no formation of silicate and carbonate minerals during quenching (Supplementary Fig. 1d). The carbonatite melts show high $\mathrm{CaO}$ contents (32.2-41.2 wt.\%) and $\mathrm{Ca} /(\mathrm{Ca}+\mathrm{Mg})$ ratios (atomic ratio, 0.62-0.81), and a large variation in $\mathrm{SiO}_{2}$ contents (1.58-13.3 wt.\%). With increasing temperature, the carbonatite melts show an increase in $\mathrm{SiO}_{2}$ and $\mathrm{MgO}$ contents, but a decrease in $\mathrm{CaO}$ and $\mathrm{Na}_{2} \mathrm{O}$ contents (Fig. 4). The $\mathrm{Ca} /(\mathrm{Ca}+\mathrm{Mg})$ ratios of near-solidus-carbonatite melts decrease from 0.81 to 0.66 with increasing pressure. Interestingly, all these melts plot on mixing lines between $\mathrm{Mg}$-calcites in the reaction zones of the subsolidus experiments and olivine at various pressures (Fig. 4). Only the experimental melts at $1200^{\circ} \mathrm{C}$ and $2.0 \mathrm{GPa}$ plot away from the mixing lines and trend towards the clinopyroxenes.

\section{Discussion}

Melting of pure calcite occurs at high temperatures of $1450-1620^{\circ} \mathrm{C}$ at $1-3 \mathrm{GPa}^{20}$ and the melting loop in the model system calciteolivine-clinopyroxene shows melting temperatures of $1100-1360^{\circ} \mathrm{C}$ at $1.0-2.8 \mathrm{GPa}^{21,22}$ (Fig. 3). Using a hydrogen-trap technique, Weidendorfer, et $\mathrm{al}^{23}$ recently found that the dry solidus of the model 
$\mathrm{SiO}_{2}$

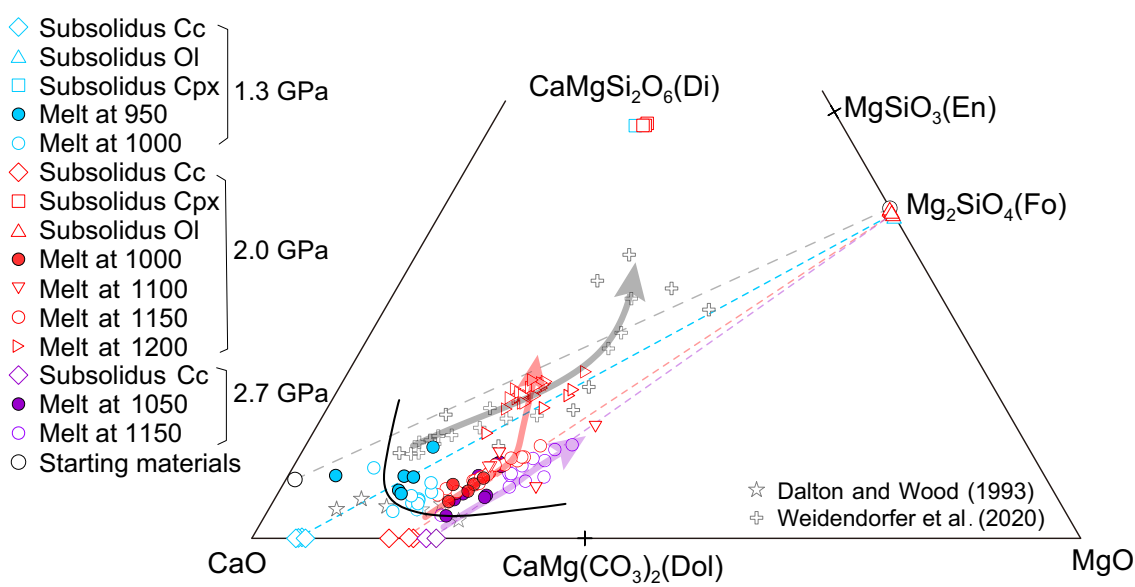

Fig. 4 Chemical compositions of experimental products. The compositions of carbonatite melts and minerals in the experiments. The minerals are from the reaction zones at the subsolidus experiments. The blue, red, and purple dotted lines represent mixing cures between olivine and Mg calcite in the reaction zones at various pressures. The red and purple arrows indicate the evolution of the melt compositions with increasing temperature. The grey dotted line represents the mixing cure between limestone and dunite using for this study. All these carbonatite melts plot on mixing lines between olivines and $\mathrm{Mg}$ calcites at various pressures, indicating no compositional contribution from clay impurities in the limestone. Carbonatite melts from water-rich calcite-olivine system ${ }^{23}$ and carbonated peridotite system ${ }^{67}$ are shown for comparison. Fo forsterite, En enstatite Di diopside, Dol dolomite.

system calcite-forsterite-diopside lies at 1.0 and $1.5 \mathrm{GPa}$ at $1225-1250{ }^{\circ} \mathrm{C}$ and $1275-1300^{\circ} \mathrm{C}$, respectively, $140{ }^{\circ} \mathrm{C}$ higher than determined by Lee, et al. ${ }^{22}$ and Lee, et al. ${ }^{21}$. They also found that the solidus of calcite-olivine-clinopyroxene with 2 wt.\% water is about 1075 and $1100{ }^{\circ} \mathrm{C}$ at 1.0 and $1.5 \mathrm{GPa}$, respectively. All previous solidi determined for the model system calcite-olivine-clinopyroxene are well above the temperatures that are present within the subduction zones and mantle wedges (Fig. 3), implying that melting would occur neither in the subducting slab nor in the mantle wedge. However, a pure carbonate system is unrepresentative for natural subduction, where most carbonate sedimentary rocks contain silicate impurities, mostly clays (Fig. 1). Our study presents the first experimental results for the melting of natural sedimentary carbonate rock in contact with peridotite. Our experiments indicate that the solidus of limestone in contact with dunite lies at $900-950^{\circ} \mathrm{C}$ at $1.3 \mathrm{GPa}, 950-1000{ }^{\circ} \mathrm{C}$ at 2.0 $\mathrm{GPa}$, and $1000-1050{ }^{\circ} \mathrm{C}$ at $2.7 \mathrm{GPa}$, about $250^{\circ} \mathrm{C}$ lower than the solidus in the calcite-olivine-clinopyroxene system ${ }^{21-23}$ (Fig. 3). In the following section, we discuss the melting relationships of limestone in contact with dunite and thus the applicable mechanism of low-temperature melting in the natural system.

Under subsolidus conditions, the limestone in the lower layer of the capsule experienced a metamorphic reaction: clay + calcite $=$ Cpx (clinopyroxene) + COH-fluid. The limestone layer shows a strong chemical potential gradient to the dunite in the upper layer of the capsule, which drives chemical exchange and interaction when they are in contact with each other. The fluid released by the metamorphic reaction appears to promote the chemical interaction between olivine and calcite 23 . Mg-Ca cation exchange occurred as indicated by the formation of $\mathrm{Mg}$-calcite and a thin clinopyroxene layer in the reaction zone (Fig. 2a):

$0.1 \mathrm{Mg}_{2} \mathrm{SiO}_{4}+\mathrm{CaCO}_{3}+\mathrm{COH}$-fluid ${ }_{1}=\mathrm{Ca}_{0.9} \mathrm{Mg}_{0.1} \mathrm{CO}_{3}+0.1$ $\mathrm{CaMgSi}_{2} \mathrm{O}_{6}+\mathrm{COH}$-fluid ${ }_{2}$ at $1.3 \mathrm{GPa}$;

$0.2 \mathrm{Mg}_{2} \mathrm{SiO}_{4}+\mathrm{CaCO}_{3}+\mathrm{COH}$-fluid ${ }_{1}=\mathrm{Ca}_{0.8} \mathrm{Mg}_{0.2} \mathrm{CO}_{3}+0.2$ $\mathrm{CaMgSi}_{2} \mathrm{O}_{6}+\mathrm{COH}$-fluid 2 at $2.0 \mathrm{GPa}$;

$0.25 \mathrm{Mg}_{2} \mathrm{SiO}_{4}+\mathrm{CaCO}_{3}+\mathrm{COH}$-fluid ${ }_{1}=\mathrm{Ca}_{0.75} \mathrm{Mg}_{0.25} \mathrm{CO}_{3}+$ $0.25 \mathrm{CaMgSi}_{2} \mathrm{O}_{6}+\mathrm{COH}$-fluid ${ }_{2}$ at $2.7 \mathrm{GPa}$. Interestingly, with increasing pressure, the $\mathrm{MgO}$ content of calcites in the reaction zone increases (Fig. 4), indicating the increasing importance of the $\mathrm{Mg}-\mathrm{Ca}$ cation exchange reaction.
Compared to the subsolidus experiments, two significant features of the experiments at $\mathrm{T}>\mathrm{T}_{\text {solidus }}$ are that carbonatite melt occurs and the thickness of the clinopyroxene layer in the reaction zone significantly increases (the clinopyroxene mode increases from $5 \mathrm{wt} \%$ to 11 wt.\%.) (Fig. 2b). The compositions of these solidus-carbonatite melts plot on mixing lines between $\mathrm{Mg}$-calcites and olivine at their corresponding pressures (Fig. 4), indicating that they are the melting products of $\mathrm{Mg}$-calcites and olivine without involvement or formation of clinopyroxene. We suggest that the reaction occurring at the solidus at various pressures is $0.1 \mathrm{Ol}$ (olivine) $+0.9 \mathrm{Mg}$-calcite $=$ carbonatite melt. As the temperature increases $\left(\mathrm{T}<1200^{\circ} \mathrm{C}\right)$, the proportion of olivine contributing to the melt increases (Fig. 4). At $1200{ }^{\circ} \mathrm{C}$ and $2.0 \mathrm{GPa}$, the clinopyroxene mode significantly decreases and carbonatite melt plots away from the mixing line between $\mathrm{Mg}$-calcites and olivine and trends towards clinopyroxene (Fig. 4), indicating the dissolution of clinopyroxene in carbonatite melts. Based on the chemical compositions of the carbonatite melts and mineral modes, the melting reaction at $1200^{\circ} \mathrm{C}$ and $2.0 \mathrm{GPa}$ is 0.14 $\mathrm{Ol}+0.74 \mathrm{Mg}$-calcite $+0.12 \mathrm{Cpx}=1.0$ carbonatite melt. These observations suggest that the involvement of clinopyroxene in the melting reaction only occurs at $1200^{\circ} \mathrm{C}$. This was also observed in the model system calcite-olivine-clinopyroxene, in which melting of clinopyroxene only occurred in high-temperature experiments with high $\mathrm{H}_{2} \mathrm{O}$ content ${ }^{23}$ (Fig. 4). The thick clinopyroxene layer in the reaction zones in the $\mathrm{T}>\mathrm{T}_{\text {solidus }}$ experiments could not be attributed to the melting reaction as indicated by the chemical compositions of carbonatite melts (Fig. 4) and its constant thickness with the increasing melting degrees at $<1200^{\circ} \mathrm{C}$. The thick clinopyroxene reaction layer could be produced by the reaction between silicate melt derived from melting of clay, olivine, and calcite: 7.4 silicate melt +4 $\mathrm{Ol}+3.8 \mathrm{Mg}$-calcite $=11 \mathrm{Cpx}+$ melt/fluid (enriched $\mathrm{H}_{2} \mathrm{O}$ and alkalis). This silicate melt was captured in the experiment at $1100{ }^{\circ} \mathrm{C}$ and $2.7 \mathrm{GPa}$ : silicate melt is distributed along the boundaries between calcite crystals in the limestone layer that is located far from the peridotite and so represents melting of the limestone alone (Supplementary Fig. 3). This is consistent with the lower melting temperature of clay than carbonate in limestones, and also with the occurrence of initial silicate melts during melting of carbonated sediments ${ }^{16,24}$. These silicate melts are characterised by high $\mathrm{CaO}$ 
and alkali contents, similar to those produced by melting of carbonated pelitic sediments (Supplementary Fig. 5) and result from the melting of clay in the former limestone. This suggests that the melting of clay in the limestone forms silicate melt that subsequently reacts with the calcite and olivine to form the thick clinopyroxene layer in the reaction zone between the limestone and dunite.

The thick clinopyroxene layer occurs together with the carbonatite melt, indicating a key role for clay in the melting of limestone in contact with dunite. Although clay impurities in limestone (7.4 wt.\%) could not impart their $\mathrm{SiO}_{2}, \mathrm{CaO}$, and $\mathrm{MgO}$ to the carbonatite melts (no involvement of clinopyroxene in melting) (Fig. 4), the introduction of alkalis $\left(\mathrm{Na}_{2} \mathrm{O}\right.$ and $\left.\mathrm{K}_{2} \mathrm{O}\right)$, $\mathrm{Al}_{2} \mathrm{O}_{3}$, and $\mathrm{H}_{2} \mathrm{O}$ to the reaction zone between the limestone and dunite through the silicate melt could significantly depress the melting temperature. The silicate melt derived from the melting of clay impurities is characterised by high alkalis $\left(\mathrm{Na}_{2} \mathrm{O}\right.$ and $\left.\mathrm{K}_{2} \mathrm{O}\right)$ and $\mathrm{H}_{2} \mathrm{O}$ that are known to cause a profound depression of the melting point of calcite ${ }^{25}$. The limestone used in this study contains 0.9 wt. $\% \mathrm{H}_{2} \mathrm{O}$ and the silicate melt derived from clays contains about 10 wt.\% $\mathrm{H}_{2} \mathrm{O}$ (Supplementary Table 2). Although we do not know the water content in the capsule accurately due to the hydrogen diffusion through the capsule walls, the solidus between 900 and $950{ }^{\circ} \mathrm{C}$ at $1.3 \mathrm{GPa}$ is much lower than in the water-saturated model system calcite-olivine-clinopyroxene from Weidendorfer, et al. ${ }^{23}$ (Fig. 3). This could not be reasonably explained by the action of water alone and needs additional factor (s) to further depress the solidus. Phase relations in the system $\mathrm{Na}_{2} \mathrm{CO}_{3}-\mathrm{CaCO}_{3}$ indicate that the addition of 10 wt.\% $\mathrm{Na}_{2} \mathrm{CO}_{3}-\mathrm{CaCO}_{3}$ could reduce the solidus by about $150^{\circ} \mathrm{C}$ at both $0.1 \mathrm{GPa}$ and $6 \mathrm{GPa}^{25,26}$. The participation of silicate melts in the contact zone between the calcite and olivine will significantly reduce the minimum melting temperature through the introduction of fusible components, such as $\mathrm{Na}_{2} \mathrm{O}, \mathrm{K}_{2} \mathrm{O}, \mathrm{H}_{2} \mathrm{O}$, and $\mathrm{Al}_{2} \mathrm{O}_{3}$. This is indicated by high alkali contents in the near-solidus carbonatite melts $\left(\mathrm{Na}_{2} \mathrm{O}+\mathrm{K}_{2} \mathrm{O}=0.58-1.03\right.$ wt.\%) (Supplementary Table 2). In summary, clay impurities play a key role in depressing the melting temperature of limestone.

Our study shows lower temperatures for the production of carbonatite melts from limestone in contact with dunite than other carbonate-bearing rocks, such as alumina-rich carbonated pelite ${ }^{27}$ and carbonated eclogite ${ }^{28}$ at about $3.0 \mathrm{GPa}$ (the solidus lies between $1100^{\circ} \mathrm{C}$ and $1200^{\circ} \mathrm{C}$ ). Also, no previous studies have produced carbonatite melts at $<2.0 \mathrm{GPa}$ in carbonated peridotite or eclogite systems (Fig. 3) because of decarbonation to produce $\mathrm{CO}_{2}$ vapour at lower pressures ${ }^{16,28-30}$. Especially, the carbonatite melts are produced at the pressure of $\geq 5.0 \mathrm{GPa}$ and $\geq 3.5 \mathrm{GPa}$ in alumina-poor carbonate pelite $^{17}$ and in alumina-rich carbonated pelite ${ }^{27}$, respectively. In contrast, our experiments indicate that limestone undergoes negligible decarbonation at low pressures, but instead can form carbonatite melt in contact with peridotite (Supplementary Fig. 1). Therefore, our data show the extension of the occurrence of carbonatite melt to shallower lithospheric mantle depths wherever limestone interacts with the mantle peridotite.

Sedimentary carbonate rocks have been suggested to experience negligible decarbonation regardless of fluid infiltration during subduction 6,31 and are the leading potential carrier of carbon to subarc depths ${ }^{6}$. Previous experimental investigation of the model system $\mathrm{CaO}-\mathrm{Al}_{2} \mathrm{O}_{3}-\mathrm{SiO}_{2}-\mathrm{H}_{2} \mathrm{O}-\mathrm{CO}_{2}$ with $5.6-21$ wt.\% $\mathrm{H}_{2} \mathrm{O}$ at 4.2 and $6.0 \mathrm{GPa}$ indicates that melting of hydrous pelagic limestones may occur in warm subduction zones ${ }^{11}$. However, natural marbles are rather dry (e.g. $<1$ wt. $\% \mathrm{H}_{2} \mathrm{O}$ for Tianshan subducted marbles ${ }^{32}$ ). Although there are effects from fluid derived from underlying dehydrating lithologies, fluid infiltration in subducted marbles mostly occurs at low pressures of $<2.0$ $\mathrm{GPa}^{9,33}$ because two-thirds of the water in the fully hydrated oceanic crust would be lost at forearc depths ${ }^{12}$. Furthermore, marbles are notably impermeable to fluid flow ${ }^{34,35}$ compared to silicate rocks, thus fluid infiltration usually occurs along a single channel in the subducted marbles 9,36 . The water content of the limestone used in our experiments is 0.9 wt.\% and was probably higher during experiments due to hydrogen diffusion, thus could represent the water content of natural marbles at subarc depths. Our experimental results show that the melting temperature of limestone in contact with peridotite is higher than temperatures likely to exist at the surface of subducting slabs at the pressures studied here (1.3-2.7 GPa; Fig. 3). This implies that the melting of limestone will not occur in subducting slabs, consistent with the common view that carbonatite melts are restricted to hot regimes.

The dynamic processes of sediment subduction depend on the competing effects of their buoyancy and viscous entrainment by the subducting slab, which are controlled by the relative density and viscosity contrasts between the sediments and overlying mantle, the thickness of the sedimentary layer, and the geotherm and dynamic parameters and processes of the subducting slab (e.g. subduction rate and slab dehydration and melting) ${ }^{37,38}$. Abundant thermomechanical ${ }^{37,39}$ and petrological-thermomechanical numerical calculations ${ }^{38,40,41}$ have been developed to investigate the fate of silicate sediments using a density of $2800-3300 \mathrm{~kg} / \mathrm{m}^{3}$ and a wet quartzite rheology, all these calculations concluded that diapirism of sediments prevails at depths of about $60-120 \mathrm{~km}$. We calculated the density and the viscosity of marbles and compared them to those of the overlying mantle (See "Methods" and Supplementary Figs. 6-7). Subducted marbles also are characterised by low density $\left(2901-3028 \mathrm{~kg} / \mathrm{m}^{3}\right.$ at $\left.<6.0 \mathrm{GPa}\right)$ compared to the mantle peridotite $\left(3200-3400 \mathrm{~kg} / \mathrm{m}^{3,42}\right)$ and are about $100 \times$ less viscous than wet olivine at $600-800^{\circ} \mathrm{C}$. Considering the similar low density and viscosity for both silicate sediments and marbles (Supplementary Figs. 6-7), previous numerical calculations on sediments are applicable for the marbles indicating that the subducted limestone-bearing sediment layer could detach from the downgoing slab to form buoyant diapirs.

To predict the depth of formation of a carbonate diapir during subduction, we have compiled the thickness of global subducted sediments, involving limestone or chalk (mostly $>250 \mathrm{~m}$, Fig. $5 a)^{3}$, and calculated the temperatures required for the formation of a sediment diapir, involving limestone. We project these on a diagram of temperature versus sediment layer thickness from the thermomechanical calculations of Behn, et al. ${ }^{37}$ (Fig. 5b) using a density contrast of $-200 \mathrm{~kg} / \mathrm{m}^{3}$ and viscosity ratio of 1:100 between the sediment and overlying mantle (Details see "Methods"). This shows that the temperatures required for sediment diapir formation range from 600 to $805^{\circ} \mathrm{C}$ (Fig. 5b), corresponding to pressures of about $2.4-3.5 \mathrm{GPa}$ on slab geotherms (Fig. 5c) ${ }^{43,44}$. Our results predict that most sediment columns involving limestone or chalk could detach from the slab at depths of $72-105 \mathrm{~km}$, consistent with previous modelling results ${ }^{37-39}$. Without considering the effect of dehydration and partial melting of the slab in the thermomechanical modelling, the results of our calculation probably represent the maximum depth of diapirism because petrological-thermomechanical modelling suggested that hydration of the overlying mantle would enhance carbonate diapirism ${ }^{38,40,41}$. Furthermore, the occurrence of clay layers within thick carbonate sequences may assist diapir formation by providing slip planes that promote detachment from the slab. Our results also indicate that the diapirism of thin sedimentary layers $(<200 \mathrm{~m})$ requires high temperatures, which could not be achieved during subduction. Therefore, thin marbles packaged in sedimentary columns in cold subduction zones would be subducted deep into the convecting mantle. The deep subduction of carbonates is evidenced by ultrahigh-pressure siliceous marbles as lenses in the Kokchetav Massif ${ }^{45}$ and as thin 

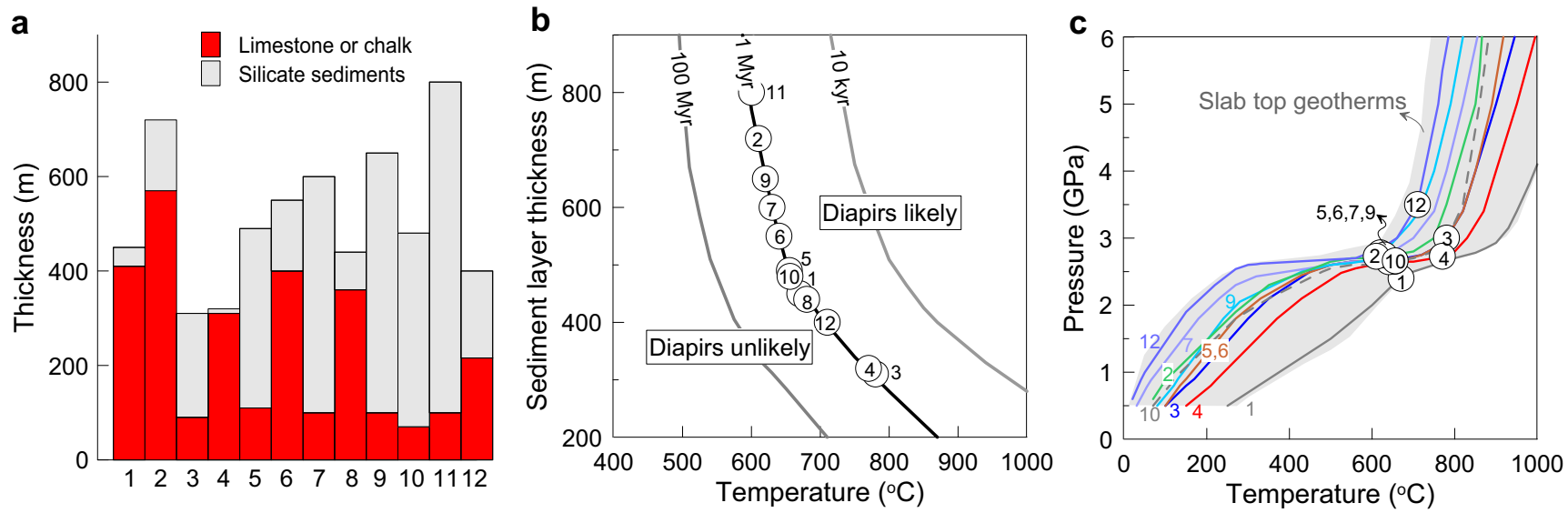

Fig. 5 Thickness of limestone-bearing sediments and buoyancy calculations. a The compiled thickness of subducted sediment columns involving limestone or chalk ${ }^{3}$. Numbers correspond to subduction zones: 1-Aegean, 2-Makran, 3-Peru, 4-Colombia-Ecuador, 5-Costa Rica, 6-Guatamala, 7-Mariana, 8-S.Luzon, 9-Solomons, 10-S. Sandwich, 11-Kamchatka, and 12-Kermadec. b Time needed to destabilise sediment layers expressed as temperature and sediment layer thickness for a density contrast of $-200 \mathrm{kgm}^{-3}$ and viscosity ratio of 1:100 between the sediment and overlying mantle from Behn, et al. ${ }^{37}$. The required temperatures for the initiation of diapirs from the subducted sediment columns with the limestone or chalk are obtained by projecting onto the $1 \mathrm{Myr}$ line which is the time of the initiation of a sediment diapir. (c) Pressure-temperature paths of the slab surface for subduction scenarios with sediment columns, involving limestone or chalk ${ }^{43}$. We calculate the pressures for the initiation of a diapir by projecting their required temperatures onto their slab geotherms.

layers in the Sulu terrane ${ }^{31}$ exhumed during subduction of continental crust.

The combination of numerical modelling with our experimental results constrains the behaviour and fate of limestone diapirs in the mantle wedge. Based on numerical modelling from Gerya and Meilick $^{38}$, two geodynamic regimes for the dynamics of sediments in the mantle wedge will occur (a) if the sediment diapirs do not melt, they may extend horizontally and thus underplate the lithosphere ${ }^{38,39}$ (Fig. 6a); (b) if abundant melting occurs, they may be emplaced into subarc crust and trans-lithospheric sedimentary diapirs could weaken the continental lithosphere to generate a weak channel ${ }^{38}$ (Fig. 6b). Which of the two geodynamic scenarios occurs also depends on the melting behaviour of other silicate sediments accompanying the limestone during subduction, as clastic sediments have lower melting temperatures than those of carbonates, as indicated by our experiments. Based on the geotherms of the mantle wedge in the two geodynamic regimes ${ }^{38}$ (Fig. 6a, b), our experimental results predict that melting of the limestone only occurs in the scenario in Fig.6a and the degree of melting of carbonate is about $20 \%$ (Fig. $6 \mathrm{c}$ ). The residues are mainly composed of refractory calcite, olivine, and clinopyroxene (Supplementary Table 1), which have a high solidus temperature and will therefore be stored in the mantle wedge in the solid state. In summary, we suggest that the majority of thick subducted limestones and chalk (> 80\%) will be stored in arc lithosphere in the solid state.

Carbonatite metasomatism derived from recycled sedimentary carbonates is sporadically found in carbonated peridotite xenoliths in lavas from arc settings ${ }^{46-48}$, consistent with a low degree of melting during subduction and diapirism of limestone. Importantly, our results suggest that subduction of limestone could result in the storage of abundant marble in arc lithosphere, a carbon reservoir that has been overlooked in previous studies. Excellent examples in previous publications witness that it is indeed widespread. Marbles from the Bohemian massif in the western Alps equilibrated at mantle conditions $(>2.5 \mathrm{GPa}$ and $1100{ }^{\circ} \mathrm{C}$ ), indicating the existence of solid-state marble for $>15 \mathrm{Ma}$ in the mantle ${ }^{49}$. Carbonatite intrusions and xenoliths along the northern margin of the North China Craton (about $10 \mathrm{Ma}$ ), which retain many geochemical features of limestones, resulted from the subduction of limestones that formed part of the Paleo-
Asian oceanic slab at $>230 \mathrm{Ma}^{50,51}$. These limestone-derived carbonatites indicate that the limestone formed part of the PaleoAsian oceanic slab that had been stored in the lithosphere mantle for at least $200 \mathrm{Ma}$. Marbles also frequently exist in the lower crust of convergent margins, such as the Calabrian massif 52 and the Bamble granulite terrane ${ }^{53}$. These meta-sediments in the lower crust were suggested to result from diapirism of sediments from the subduction zone $\mathrm{5}^{5}$. These observations suggest that subduction and diapirism could transport abundant marine carbonate rocks and store them in the continental lithosphere.

Our results have important implications for the global carbon mass balance in convergent margins and subduction zones. Previous studies have suggested that about $40-65 \%$ of subducted carbon would be released via fluids or metamorphic decarbonation reactions at forearc depths (33-53 Mt C y $\left.\mathrm{y}^{-1}\right)^{6,55}$. Most of this carbon was considered to originate from carbonated sediments and altered oceanic crust ${ }^{6}$. Only about $35 \%$ of carbon $(\sim 28$ Mt $\mathrm{C}^{-1}$ ) could be transported to arc magma source depths, mostly as marble $\left(\sim 21.4 \mathrm{Mt} \mathrm{C} \mathrm{y}^{-1}\right)^{3,6}$ (Figs. 1a and 6a). Our results suggest that these marbles would not be subducted into the deep mantle but instead stored in the lithosphere mantle or deep crust in the solid state. These imply that large-scale storage of carbon occurs overwhelmingly beneath continental margins or island arcs. Considering other potential carbon transfer mechanisms (such as carbonate dissolution and hydrous melting in subduction zones $)^{9,10}$, we suggest that less than $13 \%$ of carbon could be subducted to the deep mantle $\left(<\sim 10 \mathrm{Mt} \mathrm{C} \mathrm{y}^{-1}\right)$ (Fig. 6a).

We suggest that carbonate rocks stored in convergent margins are a key volatile source for arc volcanoes, whose emissions have been suggested to be the driver of icehouse-greenhouse intervals ${ }^{1,2}$. The heavier $\delta^{13} \mathrm{C}$ isotopes of global arc volcanic gas relative to the canonical mid-ocean ridge basalt value suggest that volcanic arc emissions are dominated by the remobilisation of crustal sedimentary carbonate rocks in the lithosphere during their ascent rather than carbon release by melt or fluid from subduction zone $e^{2,56}$. It is unclear how limestone could otherwise be emplaced into the deep crust or lithospheric mantle from the surface ${ }^{57}$. Our results indicate that the subduction and diapirism of limestone is potentially a key process for the transport and 
a

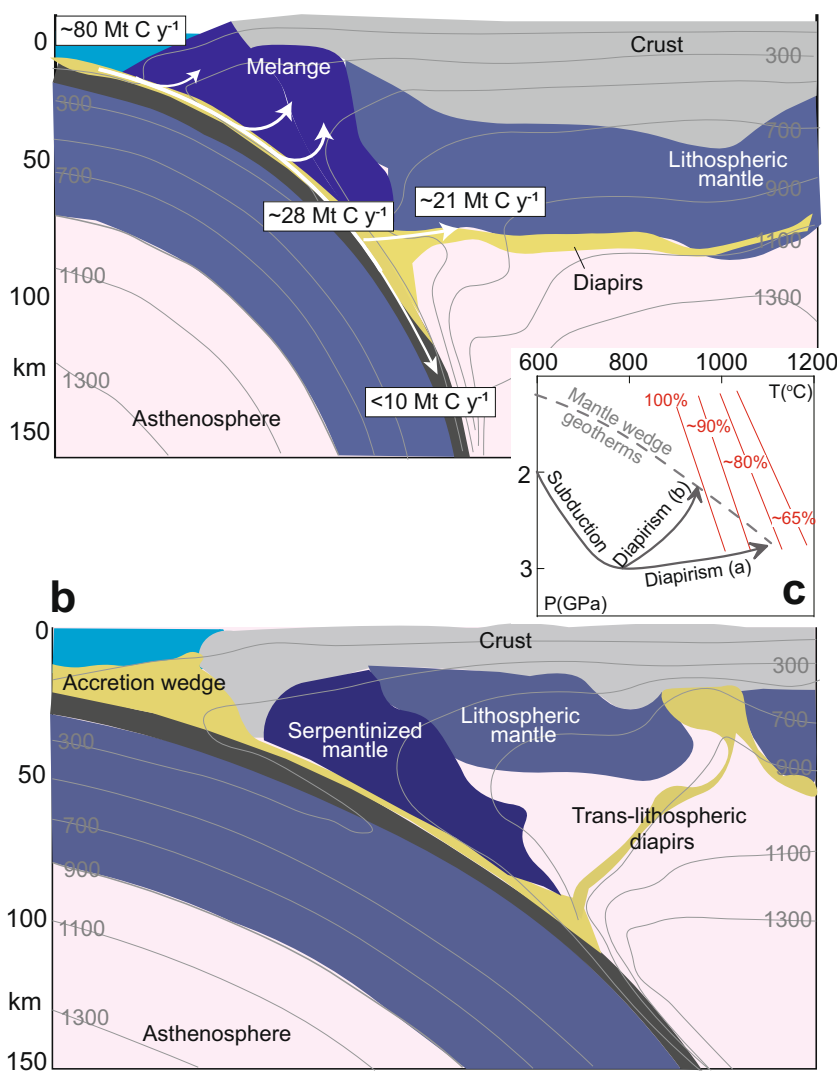

Fig. 6 Carbon fluxes and reservoirs in convergent margins. Schematic illustration showing two possible scenarios $\mathbf{a}, \mathbf{b}$ for transfer of limestonebearing sediments (light yellow) from the slab to the mantle wedge, superimposed on the numerical geodynamic model of Gerya and Meilick ${ }^{38}$ at a time shot at $>40 \mathrm{Ma}$ from subduction initiation. In the first scenario a there is no extensive melting of the sediments. In the second scenario $\mathbf{b}$, melts derived from the melting of silicate sediments rheologically weaken the lithosphere below the arc forming a weak channel into which sediment diapirs may be emplaced into subarc crust forming trans-lithospheric sedimentary plumes. The carbon fluxes (white arrows) are similar to Fig. 1a. c The schematic pressure-temperature ( $P-T)$ diagram of limestone that is subducted and entrained in a diapir for the two scenarios $\mathbf{a}$ and $\mathbf{b}$. The red lines are the proportions of residual calcite during the melting of limestone in contact with the peridotites from the experimental results in this study.

storage of sedimentary carbonate in the deep crust and the lithosphere mantle in convergent margins (Fig. 6a, b). Remobilisation of these carbonate rocks during continental collisions and continental arc flare-ups could be key dynamic processes for regulating atmospheric $\mathrm{CO}_{2}$ through time $e^{1,5,57}$.

\section{Methods}

Starting materials. The starting materials were dried at $120^{\circ} \mathrm{C}$ for $48 \mathrm{~h}$ before loading into capsules. Their chemical compositions are listed in Supplementary Table 2. We used a natural limestone from Ocean Discovery Program Expedition 115 Site 714 A located in the northern equatorial Indian Ocean (U0714A-13H-2 $\mathrm{W})$ at $5^{\circ} 03.6^{\prime} \mathrm{N}$ and $73^{\circ} 47.2^{\prime} \mathrm{E}$ to represent subducted limestone. This rock contains 7.4 wt.\% clay and its compositions are representative of fairly pure marine limestones and subducted marbles from the S.W. Tianshan UHP subduction zone $(>2.1 \mathrm{GPa})^{32}$ (Fig. 1b). The analysis on the proportion and compositions of the clay in the limestone see Analytical methods. The clay in the limestone shows high $\mathrm{SiO}_{2}$, $\mathrm{Al}_{2} \mathrm{O}_{3}$, and $\mathrm{Na}_{2} \mathrm{O}+\mathrm{K}_{2} \mathrm{O}$ contents and contains $12.1 \% \mathrm{H}_{2} \mathrm{O}$ (Supplementary Table 2), similar to the chemical compositions of subducted silicate sediments ${ }^{14}$. The bulk $\mathrm{H}_{2} \mathrm{O}$ content of this limestone was calculated by the clay water content and the modal abundance of clay in the limestone. The calculated water content of limestone is 0.9 wt.\%, similar to those of subducted metamorphic marble from Tianshan $^{32}$ (Fig. 1c). Therefore, the limestone in this study is suitable to model the melting behaviour of carbonate rock at the slab-mantle interface and the rise of diapirs through the peridotite mantle wedge.

The dunite was made up of natural olivine $(\mathrm{Mg \#}=89.6)$ picked from a lherzolite xenolith from Hannuoba, China, to represent depleted peridotite in an arc setting (Fig. 1b). Although harzburgite may be more common than dunite in the mantle wedge, dunite is used here to simplify the system and so better characterise the melting reaction, involving limestone and olivine. However, the solidus of limestone in contact with dunite would be not significantly different from that in contact with harzburgite. Compared to the dunite, the harzburgite is petrographically enriched in orthopyroxene and clinopyroxene and geochemically relatively enriched in $\mathrm{SiO}_{2}, \mathrm{Al}_{2} \mathrm{O}_{3}$, and $\mathrm{CaO}$ contents. As discussed in the main text, the melting of limestone in contact with dunite was triggered by the reaction among calcite, olivine, and the clay-derived silicate melt in the reaction zone. This reaction zone is saturated in $\mathrm{SiO}_{2}, \mathrm{Al}_{2} \mathrm{O}_{3}$, and $\mathrm{CaO}$, which was also confirmed by its thick clinopyroxene layer. The solidus of limestone could not significantly be modified when reacting with the harzburgite.

High-pressure experiments. Experiments were carried out at 1.3-2.7 GPa and 900-1200 ${ }^{\circ} \mathrm{C}$ using piston-cylinder apparatuses at Macquarie University (experiments at 1.3-2.0 GPa) and at the University of Mainz (experiments at 2.7 GPa). The starting materials were loaded into small capacity $(2.8 \mathrm{~mm}$ diameter and 3-4 mm height) $\mathrm{Ag}_{70} \mathrm{Pd}_{30}$ or $\mathrm{Au}_{80} \mathrm{Pd}_{20}$ capsules (depending on temperature) for experiments at Macquarie University. Inner capsule holders and spacers were $\mathrm{Al}_{2} \mathrm{O}_{3}$, surrounded by a graphite heater and $\mathrm{CaF}_{2}$ pressure-transmitting medium, mantled by Teflon foil. The run durations were 12-120 h (Supplementary Table 1). The capsules for experiments at the University of Mainz were $4 \mathrm{~mm}$ in diameter and $4-5 \mathrm{~mm}$ in height and made of platinum. The inner capsule holder and spacer were $\mathrm{Al}_{2} \mathrm{O}_{3}$ and surrounded by a graphite heater, inside a pressure-transmitting medium composed of $\mathrm{CaF}_{2}$. The piston-cylinder apparatus is equipped with extra cooling channels around the tungsten carbide core within the bomb plate ${ }^{58}$, ensuring rapid quenching of the carbonatite melts. To investigate the effect of experimental duration on melt composition, we performed three experiments of different duration $(12,24$, and $48 \mathrm{~h})$ at $1150^{\circ} \mathrm{C}$ and $2.0 \mathrm{GPa}$.

The comparison of the compositions of carbonatite melts in the three time-series experiments $\left(12,24\right.$, and $48 \mathrm{~h}$ at $1150{ }^{\circ} \mathrm{C}$ and $\left.2.0 \mathrm{GPa}\right)$ indicates relatively homogeneous chemical compositions for experiments of one day or longer at $1150^{\circ} \mathrm{C}(24 \mathrm{~h}$ and $48 \mathrm{~h}$ Supplementary Fig. 8). This indicates that the long duration $(>100 \mathrm{~h})$ of most of our low-temperature experiments $\left(<1050^{\circ} \mathrm{C}\right)$ ensures that these near-solidus carbonatite melts are relatively homogeneous, equilibrium compositions.

Analytical methods. Major element analyses of olivine, clinopyroxene, and carbonatite melt were performed using a wavelength dispersive JEOL JXA 8200 microprobe at the University of Mainz. Operating conditions were $15 \mathrm{kV}$ accelerating voltage and a current of $12 \mathrm{nA}$ with peak counting times between 20 and $30 \mathrm{~s}$ for analyses of clinopyroxene, silicate melt, and carbonatite melt. Olivines were measured at $20 \mathrm{kV}$ and $30 \mathrm{nA}$ with peak counting times of $150 \mathrm{~s}$ to access minor element concentrations. The beam diameter for olivine, clinopyroxene, and silicate melt was $2 \mu \mathrm{m}$. Due to the chemical heterogeneity caused by quenching of carbonatite melt, we used a larger beam diameter of $10 \mu \mathrm{m}$ for analysing major elements of carbonatite melt. A variety of minerals and synthetic materials were used as reference materials.

The major element compositions of the limestone were determined by XRF at Macquarie University. The proportion of clay was obtained by a leaching experiment using $10 \mathrm{wt} . \%$ acetic acid based on the weight of limestone and residual clay during the leaching experiment. The water content of the clay was based on loss on ignition of the clay at $800^{\circ} \mathrm{C}$. The major element composition of the clay was calculated by the proportion of clay and major elements of limestone through assuming that $\mathrm{SiO}_{2}, \mathrm{TiO}_{2}, \mathrm{Al}_{2} \mathrm{O}_{3}, \mathrm{FeO}, \mathrm{MnO}, \mathrm{Na}_{2} \mathrm{O}$, and $\mathrm{K}_{2} \mathrm{O}$ are in the clay and that carbonate is composed of $\mathrm{CaO}$ and $\mathrm{MgO}$. The total content of $\mathrm{CaO}$ and $\mathrm{MgO}$ in the clay can be obtained by $100 \%$-other major elements and water contents. To test the reliability of these calculations, we compare the calculated volatile contents of the limestone with the measured loss on ignition of the limestone (42.5 wt.\%). The volatile contents of the limestone can be calculated from the $\mathrm{CO}_{2}$ of the carbonate and water content of the clay. The calculated volatile content of the limestone is 41.9 wt.\%, consistent with the loss on ignition of the limestone. The major element compositions of the dunite were obtained by major element compositions of olivine measured by the microprobe.

Mass balance calculation. The carbonate melts and calcites show similar chemical compositions with high $\mathrm{CaO}$ contents (Supplementary Data 1) so that it is difficult to quantify the proportion of carbonate melt in a calcite matrix by mass balance calculation. Here, the proportion of carbonatite melt is calculated based on the analysis of BSE images, whereas other mineral modes were calculated by mass balance calculation. The phase modes $(M)$ were obtained by solving the following equations to minimise the $\sum \mathrm{R}^{2}$ :

$$
C_{\text {bulk C }}^{i}=\sum_{n}^{\text {phase }}\left[M_{n} \cdot C_{n}^{i}\right]
$$




$$
\sum R^{2}=\sum_{i}^{\text {component }}\left[C_{\text {bulkC }}^{i}-C_{\text {bluks }}^{i}\right]^{2}
$$

Where $i=\mathrm{SiO}_{2}, \mathrm{TiO}_{2}, \mathrm{Al}_{2} \mathrm{O}_{3}, \mathrm{MnO}, \mathrm{MgO}, \mathrm{CaO}, \mathrm{Na}_{2} \mathrm{O}$, and $\mathrm{K}_{2} \mathrm{O} ; n=$ olivine, clinopyroxene, calcite, and melts; $C_{\text {bulk }}^{i}=$ the calculated bulk concentration of component $i$ in the system; $C_{n}^{i}=$ the measured component $i$ concentration of phase $n$; $C_{\text {bulks }}^{i}=$ the $i$ concentration of the starting material in the capsule. To reduce the effect of heterogeneous compositions on clinopyroxene and calcite, we obtained the average chemical composition of many analyses. In addition, calcites in the reaction zone show much higher $\mathrm{MgO}$ than those in the limestone layer under subsolidus conditions, so that we calculate the proportions of calcite and $\mathrm{Mg}$-calcite, respectively. The detailed results are presented in Supplementary Table 1. Iron loss to $\mathrm{Ag}_{70} \mathrm{Pd}_{30}$ and $\mathrm{Au}_{80} \mathrm{Pd}_{20}$ capsules was checked through mass balance calculation: iron loss is significant ( $>20 \mathrm{wt} . \%)$ only in high-temperature runs $\left(>1150{ }^{\circ} \mathrm{C}\right)$ but is limited in most subsolidus experiments and near-solidus experiments $(<15 \mathrm{wt} . \%)$, indicating a limited effect on the solidus by iron loss.

Details of the instability calculations. We calculated the densities of the limestone used for the starting material in our high-pressure experiments as a function of temperature and pressure using Perple_X 6.9.0 ${ }^{59}$ and compared them to the density of the harzburgite ${ }^{42}$. For hot (Colombia-Ecuador) and cold (Kermadec) slab-top geotherms ${ }^{43}$, the density contrast ranges from -348 to $-228 \mathrm{~kg} / \mathrm{m}^{3}$ at $<6$ GPa (Supplementary Fig. 6). Interestingly, the magnitude of the density contrast significantly increases at a pressure of about $2.5 \mathrm{GPa}$, due to significantly increasing temperature along the subduction geotherm at this pressure. This indicates that limestone-bearing sediments are more likely to form the buoyant diapirs at $>2.5$ GPa than the silicate sediments, strengthening our calculation results of carbonate diapirs forming at the pressure of 2.4-3.5 GPa.

We calculated viscosities for dry and wet olivine ${ }^{60}$, wet quartz ${ }^{61}$, and calcite ${ }^{62,63}$ over a range of temperature for a strain rate of $10^{-14} \mathrm{~s}^{-1}$. Calcite is $100 \times$ less viscous than wet olivine and slightly less viscous than wet quartz at $600-800{ }^{\circ} \mathrm{C}$ (the approximate temperature range over which diapirs form) (Supplementary Fig. 7). Considering there is no significant viscosity difference between calcite and wet quartz, the viscosity of limestone would not significantly change with the variation of its clay content.

Using thermal-mechanical modelling, Behn, et al. ${ }^{37}$ calculated the relationship of instability time versus temperature and sediment layer thickness during subduction of sediments assuming a density contrast of $-200 \mathrm{~kg} / \mathrm{m}^{3}$ and viscosity ratio of 1:100 between the sediment and overlying mantle. Their results suggested that the sediment diapirs would form when the instability time is $\leq 1 \mathrm{Ma}$ for a subduction rate of $1-5 \mathrm{~cm} / \mathrm{yr}$. Given the density contrast of -348 to $-228 \mathrm{~kg} / \mathrm{m}^{3}$ and viscosity ratio of about 1:100 between the marble and overlying mantle, we can calculate the temperature required for the formation of a carbonate diapir, projecting the thickness of limestone-bearing sediments on the $1 \mathrm{Ma}$ curve in Fig. 5b. Based on the slab geotherms and the required temperatures, we can calculate the depth of formation of carbonate diapirs. The calculations are sensitive to the slab-top geotherm and diapirism may occur at a shallower depth if the subduction is hotter than the thermal model used in our calculation ${ }^{64}$.

\section{Data availability}

The authors declare that all data supporting the findings of this study are included within the paper and its supplementary information files.

Received: 10 March 2021; Accepted: 22 June 2021;

Published online: 22 July 2021

\section{References}

1. McKenzie, N. R. et al. Continental arc volcanism as the principal driver of icehouse-greenhouse variability. Science 352, 444-447 (2016).

2. Lee, C.-T. A. et al. Continental arc-island arc fluctuations, growth of crustal carbonates, and long-term climate change. Geosphere 9, 21-36 (2013).

3. Clift, P. D. A revised budget for Cenozoic sedimentary carbon subduction. Rev. Geophysics 55, 97-125 (2017).

4. Dasgupta, R. \& Hirschmann, M. M. The deep carbon cycle and melting in Earth's interior. Earth Planet. Sci. Lett. 298, 1-13 (2010).

5. Kelemen, P. B. \& Manning, C. E. Reevaluating carbon fluxes in subduction zones, what goes down, mostly comes up. Proc. Natl. Acad. Sci. 112, 201507889 (2015).

6. Stewart, E. M. \& Ague, J. J. Pervasive subduction zone devolatilization recycles $\mathrm{CO}_{2}$ into the forearc. Nat. Commun. 11, 6220 (2020).

7. Sieber, M. J., Hermann, J. \& Yaxley, G. M. An experimental investigation of $\mathrm{C}-\mathrm{O}-\mathrm{H}$ fluid-driven carbonation of serpentinites under forearc conditions. Earth Planet. Sci. Lett. 496, 178-188 (2018).

8. Plank, T. \& Manning, C. E. Subducting carbon. Nature 574, 343-352 (2019).
9. Ague, J. J. \& Nicolescu, S. Carbon dioxide released from subduction zones by fluid-mediated reactions. Nat. Geosci. 7, 355-360 (2014).

10. Poli, S. Carbon mobilized at shallow depths in subduction zones by carbonatitic liquids. Nat. Geosci. 8, 633-636 (2015).

11. Schettino, E. \& Poli, S. Hydrous carbonatitic liquids drive $\mathrm{CO}_{2}$ recycling from subducted marls and limestones. In Chapter 18 of Carbon in Earth's Interior (eds Manning, C.E., Lin, J.F. \& Mao W.L.) 209-221 (American Geophysical Union and John Wiley and Sons, Inc, 2020).

12. Schmidt, M. W. \& Poli, S. Devolatilization during subduction. In The Crust (ed. Rudnick, R. L.), Vol 4. of Treatise on Geochemistry 2nd Edition (eds Holland, H. D. \& Turekian, K. K.) 669-701 (Elsevier, 2014).

13. Manning, C. E., Shock, E. L. \& Sverjensky, D. A. The chemistry of carbon in aqueous fluids at crustal and upper-mantle conditions: experimental and theoretical constraints. Rev. Mineral. Geochem. 75, 109-148 (2013).

14. Plank, T. \& Langmuir, C. H. The chemical composition of subducting sediment and its consequences for the crust and mantle. Chem. Geol. 145, 325-394 (1998)

15. Tsuno, K. \& Dasgupta, R. J. Melting phase relation of nominally anhydrous, carbonated pelitic-eclogite at 2.5-3.0 GPa and deep cycling of sedimentary carbon. Contributions Mineral. Petrol. 161, 743-763 (2011).

16. Thomsen, T. B. \& Schmidt, M. W. Melting of carbonated pelites at 2.5-5.0 $\mathrm{GPa}$, silicate-carbonatite liquid immiscibility, and potassium-carbon metasomatism of the mantle. Earth Planet. Sci. Lett. 267, 17-31 (2008).

17. Tsuno, K., Dasgupta, R., Danielson, L. \& Righter, K. Flux of carbonate melt from deeply subducted pelitic sediments: Geophysical and geochemical implications for the source of Central American volcanic arc. Geophys. Res. Lett. 39, L16307 (2012).

18. Tsuno, K. \& Dasgupta, R. The effect of carbonates on near-solidus melting of pelite at $3 \mathrm{GPa}$ : relative efficiency of $\mathrm{H} 2 \mathrm{O}$ and $\mathrm{CO} 2$ subduction. Earth Planet. Sci. Lett. 319, 185-196 (2012).

19. Förster, M. W., Foley, S. F., Marschall, H. R., Alard, O. \& Buhre, S. Melting of sediments in the deep mantle produces saline fluid inclusions in diamonds. Sci. Adv. 5, 2620 (2019).

20. Irving, A. J. \& Wyllie, P. J. Subsolidus and melting relationships for calcite, magnesite and the join $\mathrm{CaCO}_{3}-\mathrm{MgCO}_{3} 36 \mathrm{~kb}$. Geochimica et. Cosmochimica Acta 39, 35-53 (1975).

21. Lee, W. J. \& Wyllie, P. J. J. The system $\mathrm{CaO}-\mathrm{MgO}-\mathrm{SiO}_{2}-\mathrm{CO}_{2}$ at $1 \mathrm{GPa}$, metasomatic wehrlites, and primary carbonatite magmas. Contributions Mineral. Petrol. 138, 214-228 (2000).

22. Lee, W. J., Huang, W. L. \& Wyllie, P. J. Melts in the mantle modeled in the system $\mathrm{CaO}-\mathrm{MgO}-\mathrm{SiO}_{2}-\mathrm{CO}_{2}$ at $2.7 \mathrm{GPa}$. Contributions Mineral. Petrol. 138, 199-213 (2000).

23. Weidendorfer, D., Manning, C. E. \& Schmidt, M. W. Carbonate melts in the hydrous upper mantle. Contributions Mineral. Petrol. 175, 72 (2020).

24. Tsuno, K. \& Dasgupta, R. The effect of carbonates on near-solidus melting of pelite at 3GPa: Relative efficiency of $\mathrm{H}_{2} \mathrm{O}$ and $\mathrm{CO}_{2}$ subduction. Earth Planet. Sci. Lett. 319-320, 185-196 (2012).

25. Cooper, A. F., Gittins, J. \& Tuttle, O. F. The system $\mathrm{Na}_{2} \mathrm{CO}_{3}-\mathrm{K}_{2} \mathrm{CO}_{3}-\mathrm{CaCO}_{3}$ at 1 kilobar and its significance in carbonatite petrogenesis. Am. J. Sci. 275, 534-560 (1975).

26. Shatskiy, A. et al. New experimental data on phase relations for the system $\mathrm{Na}_{2} \mathrm{CO}_{3}-\mathrm{CaCO}_{3}$ at $6 \mathrm{GPa}$ and $900-1400{ }^{\circ} \mathrm{C}$. Am. Mineralogist 98, 2164-2171 (2013).

27. Thomsen, T. B. \& Schmidt, M. W. Melting of carbonated pelites at 2.5-5.0 Gpa, silicate-carbonatite liquid immiscibility, and potassium-carbon metasomatism of the mantle. Earth Planet. Sci. Lett. 267, 17-31 (2008).

28. Dasgupta, R., Hirschmann, M. M. \& Withers, A. C. Deep global cycling of carbon constrained by the solidus of anhydrous, carbonated eclogite under upper mantle conditions. Earth Planet. Sci. Lett. 227, 73-85 (2004).

29. Falloon, T. J. \& Green, D. H. The solidus of carbonated, fertile peridotite. Earth Planet. Sci. Lett. 94, 364-370 (1989).

30. Hammouda, T. High-pressure melting of carbonated eclogite and experimental constraints on carbon recycling and storage in the mantle. Earth Planet. Sci. Lett. 214, 357-368 (2003).

31. Massonne, H.-J. Phase relations of siliceous marbles at ultrahigh pressure based on thermodynamic calculations: examples from the Kokchetav Massif, Kazakhstan and the Sulu terrane, China. Geol. J. 46, 114-125 (2011).

32. Tao, R., Zhang, L., Li, S., Zhu, J. \& Ke, S. Significant contrast in the Mg-C-O isotopes of carbonate between carbonated eclogite and marble from the S.W. Tianshan UHP subduction zone: evidence for two sources of recycled carbon. Chem. Geol. 483, 65-77 (2018).

33. Schumacher, J. C., Brady, J. B., Cheney, J. T. \& Tonnsen, R. R. Glaucophanebearing marbles on Syros, Greece. J. Petrol. 49, 1667-1686 (2008).

34. Galvez, M. E. \& Pubellier, M. How do subduction zones regulate the carbon cycle? In chapter 10 of Deep Carbon: Past to Present (eds Orcutt B., Daniel I. \& Dasgupta R.) 276-312 (Cambridge University Press, 2019).

35. Bickle, M., Chapman, H., Wickham, S. \& Peters, M. T. Strontium and oxygen isotope profiles across marble-silicate contacts, Lizzies Basin, East Humboldt 
Range, Nevada: constraints on metamorphic permeability contrasts and fluid flow. Contributions Mineral. Petrol. 121, 400-413 (1995).

36. Guo, S. et al. Multiple episodes of fluid infiltration along a single metasomatic channel in metacarbonates (Mogok Metamorphic Belt, Myanmar) and implications for $\mathrm{CO}_{2}$ release in orogenic belts. J. Geophys. Res.: Solid Earth 126, e2020JB020988 (2021).

37. Behn, M. D., Kelemen, P. B., Hirth, G., Hacker, B. R. \& Massonne, H.-J. Diapirs as the source of the sediment signature in arc lavas. Nat. Geosci. 4, 641-646 (2011).

38. Gerya, T. V. \& Meilick, F. I. Geodynamic regimes of subduction under an active margin: effects of rheological weakening by fluids and melts. $J$. Metamorphic Geol. 29, 7-31 (2011).

39. Currie, C. A., Beaumont, C. \& Huismans, R. S. The fate of subducted sediments: a case for backarc intrusion and underplating. Geology 35, 1111-1114 (2007).

40. Gorczyk, W., Gerya, T. V., Connolly, J. A. D., Yuen, D. A. \& Rudolph, M. Large-scale rigid-body rotation in the mantle wedge and its implications for seismic tomography. Geochem. Geophys. Geosyst. 7, Q05018 (2006).

41. Gerya, T. V., Connolly, J. A., Yuen, D. A., Gorczyk, W. \& Capel, A. M. Seismic implications of mantle wedge plumes. Phys. Earth Planet. Inter. 156, 59-74 (2006).

42. Jull, M. \& Kelemen, P. On the conditions for lower crustal convective instability. J. Geophys. Res. 106, 6423-6446 (2001).

43. Syracuse, E. M., van Keken, P. E. \& Abers, G. A. The global range of subduction zone thermal models. Phys. Earth Planet. Inter. 183, 73-90 (2010).

44. Wada, I. \& Wang, K. Common depth of slab-mantle decoupling: Reconciling diversity and uniformity of subduction zones. Geochem. Geophys. Geosyst. 10, Q10009 (2009).

45. Kaneko, Y. et al. Geology of the Kokchetav UHP-HP metamorphic belt, Northern Kazakhstan. Isl. Arc 9, 264-283 (2000).

46. Sapienza, G. T., Scambelluri, M. \& Braga, R. Dolomite-bearing orogenic garnet peridotites witness fluid-mediated carbon recycling in a mantle wedge (Ulten Zone, Eastern Alps, Italy). Contrib. Miner. Pet. 158, 401-420 (2009).

47. Ducea, M. N., Saleeby, J., Morrison, J. \& Valencia, V. A. Subducted carbonates, metasomatism of mantle wedges, and possible connections to diamond formation: an example from California. Am. Mineralogist 90, 864-870 (2005).

48. Chen, C. F. et al. Carbonated sediment recycling and its contribution to lithospheric refertilization under the northern North China Craton. Chem. Geol. 466, 641-653 (2017).

49. Becker, H. \& Altherr, R. Evidence from ultra-high-pressure marbles for recycling of sediments into the mantle. Nature 358, 745-748 (1992).

50. Liu, Y. S. et al. First direct evidence of sedimentary carbonate recycling in subduction-related xenoliths. Sci. Rep. 5, 11547 (2015).

51. Chen, C. F. et al. Paleo-Asian oceanic slab under the North China craton revealed by carbonatites derived from subducted limestones. Geology 44, 1039-1042 (2016).

52. Schenk, V. Petrology of felsic granulites, metapelites, metabasics, ultramafics, and metacarbonates from Southern Calabria (Italy): prograde metamorphism, uplift and cooling of a former lower crust. J. Petrol. 25, 255-296 (1984).

53. Touret, J. L. Fluid regime in southern Norway: the record of fluid inclusions. In The Deep Proterozoic Crust in the North Atlantic Provinces (eds Tobi, A. C. \& Touret, J. L.) 517-549 (Springer, 1985).

54. Hacker, B. R., Kelemen, P. B. \& Behn, M. D. Differentiation of the continental crust by relamination. Earth Planet. Sci. Lett. 307, 501-516 (2011).

55. Barry, P. H. et al. Forearc carbon sink reduces long-term volatile recycling into the mantle. Nature 568, 487-492 (2019).

56. Mason, E., Edmonds, M. \& Turchyn, A. V. Remobilization of crustal carbon may dominate volcanic arc emissions. Science 357, 290-294 (2017).

57. Lee, C.-T. A. \& Lackey, J. S. Global continental arc flare-ups and their relation to long-term greenhouse conditions. Elements 11, 125-130 (2015).

58. Ziaja, K., Foley, S. F., White, R. W. \& Buhre, S. Metamorphism and melting of picritic crust in the early Earth. Lithos 189, 173-184 (2014).

59. Connolly, J. A. D. Computation of phase equilibria by linear programming: a tool for geodynamic modeling and its application to subduction zone decarbonation. Earth Planet. Sci. Lett. 236, 524-541 (2005).

60. Hirth, G. \& Kohlstedt, D. Rheology of the upper mantle and the mantle wedge: a view from the experimentalists. In Inside the Subduction Factory, Volume 138 (ed. Eiler, J.) 83-106 (American Geophysical Union, 2003).
61. Hirth, G., Teyssier, C. \& Dunlap, J. W. An evaluation of quartzite flow laws based on comparisons between experimentally and naturally deformed rocks. Int. J. Earth Sci. 90, 77-87 (2001).

62. Schmid, S. M., Paterson, M. S. \& Boland, J. N. High temperature flow and dynamic recrystallization in carrara marble. Tectonophysics 65, 245-280 (1980).

63. Heard, H. C. \& Raleigh, C. B. Steady-state flow in marble at $500^{\circ}$ to $800^{\circ} \mathrm{C}$. GSA Bull. 83, 935-956 (1972).

64. Penniston-Dorland, S. C., Kohn, M. J. \& Manning, C. E. The global range of subduction zone thermal structures from exhumed blueschists and eclogites: rocks are hotter than models. Earth Planet. Sci. Lett. 428, 243-254 (2015).

65. Plank, T. The Chemical Composition of Subducting Sediments. In In The Crust (ed. Rudnick, R. L.), Vol 4. of Treatise on Geochemistry 2nd Edition (eds Holland, H. D. \& Turekian, K. K.) 607-629 (Elsevier, 2014).

66. O’Relly, S. Y. \& Griffin, W. L. A xenolith-derived geotherm for southeastern Australia and its geophysical implications. Tectonophysics 111, 41-63 (1985).

67. Dalton, J. A. \& Wood, B. J. The compositions of primary carbonate melts and their evolution through wallrock reaction in the mantle. Earth Planet. Sci. Lett. 119, 511-525 (1993).

\section{Acknowledgements}

We thank Dr. John Adam, Dr. Stephan Buhre, and Dr. Slava Shcheka for assistance with experimental apparatuses, and Dr. Mingdi Gao and Dr. Xiong Wang for discussion on density and viscosity calculations. SFF and CC are funded by ARC grant FL180100134 This research is co-supported by NSFC (41530211), Key R\&D Program of China (2019YFA0708400), and SKL-GPMR (MSFGPMR01). MWF is funded by Macquarie University grant MQRF0001074-2020. The Ocean Discovery Project provided the marine limestone sample.

\section{Author contributions}

S.F.F and C.C designed the study. C.C and M.W.F. carried out the experiments and performed analytical measurements. C.C wrote the manuscript and all authors contributed to interpreting data and revising the manuscript.

\section{Competing interests}

The authors declare no competing interests.

\section{Additional information}

Supplementary information The online version contains supplementary material available at https://doi.org/10.1038/s41467-021-24750-0.

Correspondence and requests for materials should be addressed to C.C. or Y.L.

Peer review information Nature Communications thanks the anonymous reviewers for their contribution to the peer review of this work. Peer reviewer reports are available.

Reprints and permission information is available at http://www.nature.com/reprints

Publisher's note Springer Nature remains neutral with regard to jurisdictional claims in published maps and institutional affiliations.

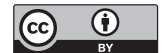

Open Access This article is licensed under a Creative Commons Attribution 4.0 International License, which permits use, sharing, adaptation, distribution and reproduction in any medium or format, as long as you give appropriate credit to the original author(s) and the source, provide a link to the Creative Commons license, and indicate if changes were made. The images or other third party material in this article are included in the article's Creative Commons license, unless indicated otherwise in a credit line to the material. If material is not included in the article's Creative Commons license and your intended use is not permitted by statutory regulation or exceeds the permitted use, you will need to obtain permission directly from the copyright holder. To view a copy of this license, visit http://creativecommons.org/ licenses/by/4.0/.

(C) The Author(s) 2021 